\title{
村田 慧
}

東京大学生産技術研究所

助教

有機金属フタロシアニン錯体の光線力学的効果に関する研究

\section{$\S 1$. 研究成果の概要}

本研究は、生体透過性の高い赤色光および有 機金属フタロシアニン錯体を用いて、細胞内で機 能性分子を放出する新しい反応システムの構築を 目的とする(図1)。

本年度は、光励起に伴う軸位の金属一炭素結 合の活性化により、種々の機能性アルデヒドを放

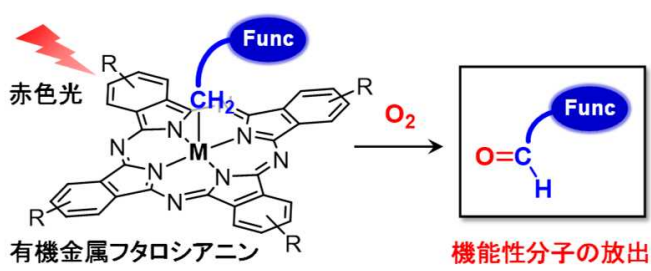

図1. 本研究の概念図 出可能な有機ロジウム(III)フタロシアニン錯体の光反応開発に取り組んだ。特に、ベンジルロジウ ム(III)フタロシアニン錯体は、芳香族アルデヒド類の放出における、よい前駆体モデルと考えること ができる。そこで、同錯体の新規合成法について検討し、錯体 1 の合成・単離に成功した。 1 は、卜 ルエン中、 $655 \mathrm{~nm}$ にフタロシアニン環の $\pi-\pi *$ 遷移に由来する強く鋭い吸収帯を示し、赤色光 を効率よく吸収することが分かった。そこで、1の溶液に対し、酸素共存下で赤色定常光を照射す ると、1の速やかな転化が観測され、ベンズアルデヒドが良好な収率で生成することを見出した(図 2)。この結果より、軸位にベンジル骨 格を有するロジウム(III)フタロシアニン 錯体は、赤色光による芳香族アルデヒ ド類の放出に有用であることが示唆さ れた。
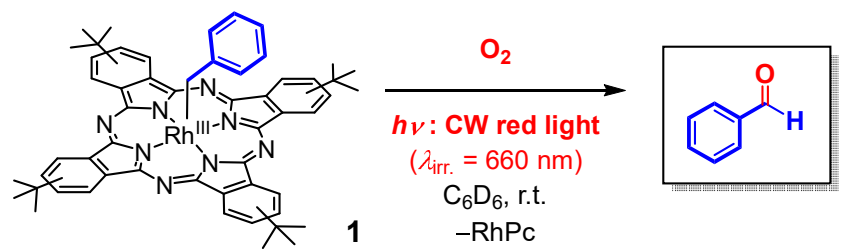

図2.ベンジルロジウム(III)フタロシアニン錯体の光反応 